\title{
H2AC16 wt Allele
}

National Cancer Institute

\section{Source}

National Cancer Institute. H2AC16 wt Allele. NCI Thesaurus. Code C162905.

Human H2AC16 wild-type allele is located in the vicinity of $6 \mathrm{p} 22.1$ and is approximately 1 $\mathrm{kb}$ in length. This allele, which encodes histone H2A type 1 protein, plays a role in histonemediated cellular processes. 